\section{LCA as Comparative Tool for Concrete Columns and Glulam Columns}

\section{Gámez-García Diana Carolina}

Universidad Politécnica de Cataluña, Escuela Técnica Superior de Arquitectura de Barcelona Av. Diagonal, 649-651, 08028, Barcelona, Spain

\section{Gómez-Soberón José Manuel*}

Universidad Politécnica de Cataluña, Escuela Politécnica Superior de Edificación de Barcelona Av. Doctor Marañón, 44-50, 08028, Barcelona, Spain

\section{Corral-Higuera Ramon, Almaral-Sánchez Jorge Luis}

Universidad Autónoma de Sinaloa, Facultad de Ingeniería Mochis

Fuente de Poseidón y Ángel Flores s/n pte., 81223, Los Mochis, Sinaloa, Mexico

\section{Gómez-Soberón María Consolación}

Universidad Autónoma Metropolitana, Facultad de Ingeniería Civil

Av. San Pablo No. 180. Col. Reynosa Tamaulipas, 02200.

Delegación Azcapotzalco. Distrito Federal. Mexico

\section{Gómez-Soberón Luis Alberto}

Alonso y Asociados, Distrito Federal. Mexico

${ }^{*}$ Corresponding author: josemanuel.gomez@upc.edu

$\Gamma$

crossef http://dx.doi.org/10.5755/j01.sace.11.2.10291

Nowadays, in the construction sector, some methods are being investigated to detect and minimize their environmental impact. The Life Cycle Assessment (LCA) is a tool that allows the evaluation of the environmental burden of a product or process, with a scientific recognition increment; and therefore the aim of this work is to verify the feasibility of the use of LCA in the construction sector. For this purpose, the environmental impacts of the use of conventional reinforced concrete (RC) columns, and Glulam $(G)$ as an alternative material, were compared. The scope of the LCA included the extraction and manufacture of materials and construction of the columns; the software tools used were LCA Manager 1.3 and database Ecoinvent 2.0. The study showed that the most critical stage is the production of materials. RC reports 3.5 times more damage to ecosystem quality, requires a $32 \%$ more extraction of natural resources, and produces effects on human health $53 \%$ higher than $G$; while $G$ generates 108 times more damage to land occupation; however, considering environmental measures, this effect can be mitigated, since it is a material 100\% renewable. Finally, it was verified that LCA is a feasible option to use in the construction field and, it provides a wide range of results.

KEYWORDS: Glulam, LCA, Reinforced-Concrete, Sustainable-Construction.
JSACE 2/11

LCA as Comparative Tool for Concrete Columns and Glulam Columns

Received 2015/02/02

Accepted after revision 2015/06/01

\section{ktu \\ 1922}

Journal of Sustainable Architecture and Civil Engineering Vol. 2 / No. 11 / 2015 pp. $21-31$

DOI 10.5755/j01.sace.11.2.10291 (c) Kaunas University of Technology 
The construction sector transforms the environment with important consequences and impacts on it. It is responsible for high-energy consumption, $30-40 \%$ of total worldwide energy (Ortiz et al. 2009, Erlandsson and Borg 2003, Kellenberger and Althaus 2008, Ramesh et al. 2010, Xing et al. 2008, Carvalho-Filho 2001). It is also a waste generator; an emitter of greenhouse gases, $40 \%$ of total emissions (Ramesh et al. 2010, Carvalho-Filho 2001); responsible for environmental damage; and consumer of natural resources, 40\% on a global scale (Ortiz et al. 2009, Erlandsson and Borg 2003, Kellenberger and Althaus 2008, Ramesh et al. 2010, 0 'Reilly-Díaz et al. 2010, Xing et al. 2008, Zhang et al. 2006, Carvalho-Filho 2001).

The implementation of reduction strategies (in energy demand, material consumption and waste generation, effluents and emissions generation) may be alternatives to mitigate these problems. However, it is necessary to unite criteria and channel them to a single address: sustainability. LCA of materials is the current tool, which is been implemented for this purpose. In some previous studies (Ortiz et al. 2009), there is evidence of its use in the construction sector since the 90s with satisfactory results.

In spite of the fact that LCA is a promising tool to improve the sustainable aspect of the construction sector, it still requires further studies. For example, Peuportier (2000) concluded that using the LCA as evaluative tool is still difficult, due to the lack of information. While more recently, Ortiz et al. (2009) concluded that the use of LCA is very important to minimize the environmental impact, improving the sustainability indicators. For what, Khasreen et al. (2009) carried out a review about the LCA in construction, concluding that despite the limitations that still exist, LCA is a powerful tool for the evaluation of environmental impact of buildings.

One limitations of the LCA in construction is the lack of specific Life Cycle Inventory (LCI) in each region or sector, especially in developing countries. The development of specific inventory of each area is necessary, for example, in Spain there is not an exclusive database, so that in some studies, such as this, the importance of creating local inventories with specific information is emphasize. Althaus et al. (2005), analyzed the Swiss database Ecoinvent (LCl based on Swiss and European generic data). While Bilec et al. (2006) proposed a hybrid model of LCA and analyzed existing models. Both concluded that the creation of local, current and specific $\mathrm{LCl}$ in each geographical region and construction area is necessary.

Moreover, although the operation phase is the most representative in the environmental impact of buildings, approximately $80-90 \%$ of the entire lifecycle (Cabeza et al. 2014, Khasreen, Banfill and Menzies 2009, Ramesh et al. 2010, Radhi and Sharples 2013, Utama et al. 2012), the construction (and pre-construction) phase should not be neglected for its high environmental impact and because the energy efficiency of the operation stage depends on it. It can also provide positive impacts at the end of the life cycle, considering potential return materials to new lifecycles.

According to the above, studies have been carried out to identify the impacts of the different stages in the life cycle. Venkatarama et al. (2003) studied about embodied energy, concluding that the use of alternative materials and high-energy efficiency is very important for the environment. Meanwhile, Horvath et al. (2005) when studying the construction and pre-construction phase (stage of embodied energy) of buildings, concluded that the environmental effects can be mitigated carefully selecting the primary materials, secondary materials and construction equipment. In the same year Pérez-García et al. (2005), found that woodland materials generate a high reduction in atmospheric carbon emissions in housing construction. Similarly Rivela et al. (2006) suggested promoting the use of renewable energies and materials to avoid damage to natural resources.

In the same subject Asif et al. (2007), evaluating the embodied energy of materials, found that concrete consumes more energy than Wood. Zabalza et al. (2009) proposed and implemented a simplified LCA methodology and concluded that energy certifications must consider the use of renewable and recyclable materials, among other technologies. Aye et al. (2012) found that the use 
of prefabricated materials (such as modular steel and wood) is an option with environmental advantages because it incorporates broader life cycles. Dodoo et al. (2014) showed that wood-building systems could contribute to improve the resource efficiency in the buildings construction.

The main objective of the research is to verify the feasibility of the use of LCA as an evaluative tool in the construction of typical structural elements of a building, in this case, columns. The structural elements are analyzed considering two alternative materials: RC and G, both with capacity to resist structural loads and durability.

\section{Characteristics of the study sample}

For this research, a typical attached housing is used, evaluated according to the protocols of the standards ISO 14040 for LCA (2006). The property is located in 41040' 5.24" N, 0201.5'20.03" E, Municipality of L'Ametlla, Barcelona, Spain. It is a three-storey building, with 60 columns (basement B, ground floor GF, and plant type PT), its general details are presented in Table 1; likewise, the quantities of material used to manufacture the columns (considering a density to the RC of $2400 \mathrm{~kg} / \mathrm{m}^{3}$, and a density to the $\mathrm{G}$ of $410 \mathrm{~kg} / \mathrm{m}^{3}$ ) are indicated. The general details of the sections evaluated equivalent for both cases are presented in Fig. 1.

\begin{tabular}{|c|c|c|c|c|c|c|c|c|}
\hline \multirow{3}{*}{ త্ } & \multirow{3}{*}{ 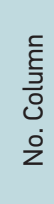 } & \multirow{3}{*}{ 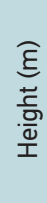 } & \multicolumn{3}{|c|}{$\mathrm{RC}$} & \multicolumn{3}{|c|}{ G } \\
\hline & & & \multirow{2}{*}{$\begin{array}{l}\text { Column dimension } \\
\qquad(\mathrm{cm} \times \mathrm{cm})\end{array}$} & \multicolumn{2}{|c|}{ Quantity } & \multirow{2}{*}{$\begin{array}{l}\text { Column dimension } \\
\qquad(\mathrm{cm} \times \mathrm{cm})\end{array}$} & \multicolumn{2}{|c|}{ Quantity } \\
\hline & & & & (ton) & $\left(m^{3}\right)$ & & (ton) & $\left(m^{3}\right)$ \\
\hline$B$ & 6 & 2.3 & \multirow{3}{*}{$30 \times 30$} & 2.98 & 1.2 & \multirow{3}{*}{$27 \times 24$} & 0.36 & 0.9 \\
\hline GF & 33 & 2.8 & & 20.00 & 8.3 & & 2.45 & 6.0 \\
\hline PT & 21 & 3.6 & & 16.50 & 6.9 & & 2.01 & 4.9 \\
\hline
\end{tabular}

The study sample consists of two attached homes designed as a single volume, both have identical dimensions and characteristics (together $446 \mathrm{~m}^{2}$ of floor area), share an intermediate wall (including columns and beams) and the parcel where are located is $27 \mathrm{~m} \times 39 \mathrm{~m}$ $1053 \mathrm{~m}^{2}$. Each dwelling has an average occupation capacity for six people and

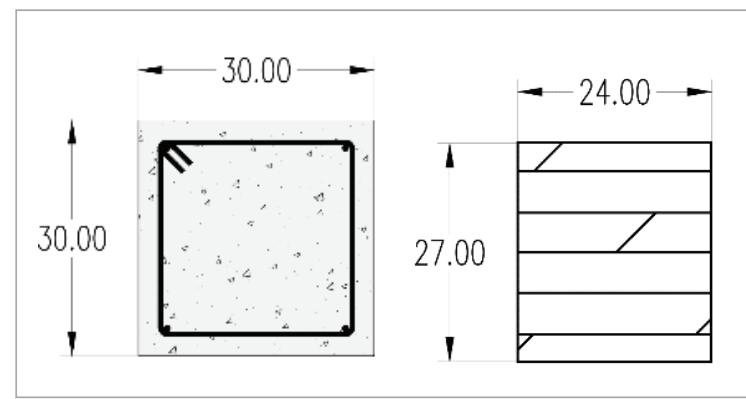
the set is located $33 \mathrm{~km}$ from the Catalan Capital. The project satisfies the basic requirements of Spanish and Catalan legal framework, listed in Table 2.

The building structure contains a self-supporting unidirectional slab with semi-joists of RC, beams and columns of RC. It has spread and isolated footings in foundation. Table 3 shows the description of the structural elements.

$\mathrm{G}$ was used as an alternative material, GL28c resistant class, of fir tree with melanin glue for interior columns and resorcinol glue for exterior columns, with a compressive strength parallel to the fibers of $24 \mathrm{MPa}$ and flexural strength of $28 \mathrm{MPa}$.

\section{Methodology}

\section{Table 1}

General details of the columns

\section{Fig. 1}

a) Column section of RC $(\mathrm{cm}) \mathrm{b})$ Column section of $\mathrm{G}(\mathrm{cm})$ 


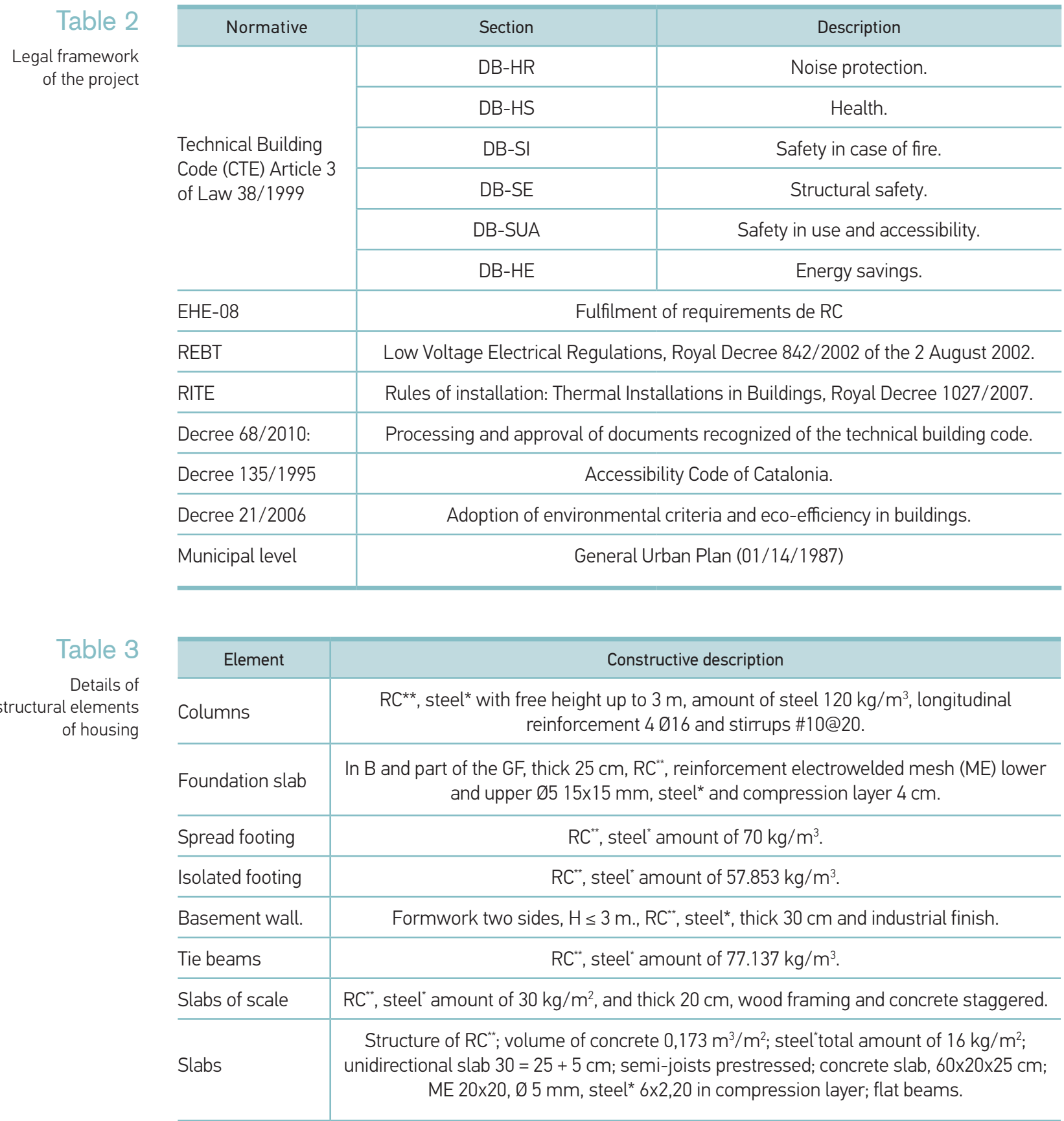

Note: " UNE-EN 10080 B500S, "HA-25/B/20/Ila

\section{Goal and scope of the LCA}

The objective of the analysis is to compare the environmental impact between RC columns and $G$ columns, for a dwelling. The study was conceived from a design point of view, in order to help the constructor and the designer to take assertive decisions about the most favorable choice of two types of columns, before construction.

The software used was LCA Manager 1.3, which allows evaluating, quantifying and qualifying all employed resources, managing waste, discharges and emissions throughout the system, 
with the limitations of border specified. The system has been limited to the pre-construction (extraction of raw materials and production) until the construction of the columns, this because, these stages allow to identify the most important affectations with whom the columns contribute in the system. Fig. 2 presents the schema of the system used.

LCA is a methodology that allowed evaluate the environmental burdens of products and processes (goods and services) during their life cycle, achieving apply the concept of sustainability from the analysis that goes "cradle to grave" (Ortiz et al. 2009, Erlandsson and Borg 2003, 0'Reilly-Díaz et al. 2010, Xing et al. 2008, Zhang et al. 2006, Carvalho-Filho 2001, Simpple 2010). The description of the methodology is based on international standards ISO 14040 series (13), which consists of four different analytical steps: defining the goal and scope, inventory creation, impact assessment and finally the interpretation of results; being the final report, the last element that completes the phases of LCA (Ortiz et al. 2009, Carvalho-Filho 2001, Simpple 2010).

As functional unit was selected the $\mathrm{m}^{3}$ of material employed in the fabrication of the columns, the foregoing by the fact that these have different sectional dimensions (the difference in the physical, mechanical and elastic characteristics of the RC and G). The first of these (RC) is considered conventional in the construction of housing, while the second $(G)$ is an alternative; for this research, both materials are comparable as vertical structural elements. Use $\mathrm{m}^{3}$ as comparable unit, permits to unify and to simplify the comparison between them, in addition to being feasible for using in others investigations of structural elements, despising the dimensions of the columns (height and section). Moreover, common used functional units, such as $\mathrm{m}^{2}$, are not feasible to use in columns because its distribution in the construction is not uniform (unless to carried out the LCA for all building elements and systems). For the case of linear meter, this is not representative (for differences in the dimensions of the columns and their physical characteristics).

With regard to materials of study, RC was selected for its high environmental affectation since it requires significant amounts of non-renewable materials and produces high power consumption for its constitution and manufacturing (Ortiz 2009, Gaimster and Munn 2007, Deshpande 2011 , Xiao et al. 2012); so it is necessary to study alternatives to it. Among the possible options, replace it with an alternative material (G) seems more appropriate than the partial substitution of the constituent materials (fly ash, blast furnace slag and silica fume by cement; and recycled aggregates by natural aggregates).

In accordance with the foregoing, some action plans for climate have been established, proposing the use of wood in construction as a mitigation measure of emissions and combat for climate change (Gobierno-Vasco 2009). These ones indicate that the use of $\mathrm{G}$ panels can save energy by $35 \%$ during the life cycle, and reduce $97 \%$ in $\mathrm{CO}_{2}$ emissions compared to traditional $\mathrm{RC}$ and steel frames structures (Fernández et al. 2014); thus allowing obtains a primary energy balance with an more basic life cycle (Dodoo et al. 2014).
Fig. 2

System of LCA of the construction of columns 


\section{Inventory Analysis}

Ecoinvent V2.01 (2007) database was used for the inventory in this study. This database has been developed by Swiss technology (Ortiz, Castells and Sonneman 2010), and consist on Swiss data and in some cases on average European data (Ecoinvent 2015). Despite this, Ecoinvent has been selected due to limited inventory information found in the Spanish sector and, specifically in the construction area. Given this limitation, only data from the European average were selected (generic data, no Swiss data).

The project data were quantified from the amounts of reinforced concrete (compressive strength $25 \mathrm{~N} / \mathrm{mm}^{2}$ ) required for preparation of the columns (Table 1), and considering an amount of steel $120 \mathrm{~kg} / \mathrm{m}^{3}$. Similarly, the amounts for the $\mathrm{G}$ of the proposed alternative design were determined, considering glued laminated timber of indoor use (for indoor columns) and outdoor use (for external columns) of six layers ( $45 \mathrm{~cm}$ each). In the LCA Manager 1.3 were entered these data, for the calculation and analysis of results.

Ecoinvent (2015) is the database world leader and the most used as a $\mathrm{LCl}$, being recognized for having consistent, transparent and timely data; contains international information of $\mathrm{LCl}$ for the supply of energy, resource extraction, and supply of materials, use of chemicals, metals, agriculture, services, waste management and transport. This database is used by 4,500 persons in over 40 countries and is included in many of the leader tools of LCA software (such as LCA Manager), as well as several tools of eco-design for construction, waste management or product design (Ecoinvent Centre 2015).

\section{Environmental impact analysis}

The environmental impact assessment was performed using the LCA Manager 1.3, a tool for environmental assessment based on the methodology of LCA (ISO 14040/44: 2006) for industrial products and processes, created by SIMPPLE (2010). This tool supports the eco-innovation and allows to quantify and communicate the environmental profile of products and/or processes taking into account their entire life cycle (it can be compared by its function with tools like Simapro, Bees, Gabi). The calculation through LCA Manager, is carried out by six stages of calculation: characterization, inventory, indicators, impacts, results and graphs (SIMPPLE 2010).

The impact categories studied in this research refers to the energy consumption, natural resources and emissions resulting from the processes of each material used and its impact on the environment. These categories are the most representative in the stages studied (extraction, production and construction), also are included in the Eco-indicator99, method that was selected due to its wide use and recognition in Europe, and included in LCA Manager 1.3.

The Eco-indicators 99 selected for the LCA, permits to study and report the effects of the investigated processes ( $\mathrm{RC}$ and $\mathrm{G}$ ) in the following sections:

1 Ecosystem Quality (acidification-eutrophication, eco-toxicity and land occupation).

2 Natural resources consumption (mineral extraction, and fossil fuels consumption).

3 Health (climate change, ozone layer depletion, ionizing radiation, respiratory effects or carcinogenic).

Eco-indicator 99 is a method of Environmental Impact Assessment, which weights the study to highlight the environmental damage, modeling the resource use and emissions effects on human health, considering the quality of the ecosystems and consumption of natural resources. Finally, the impact on these three security parameters are weighted to provide an indicator with a single component (Kellenberger and Althaus 2009), which allows grouping and comparing. 
The LCA, through the method Ecoindicator99, has helped to obtain data about the environmental impact of the structural elements studied (RC and G columns) determining that, of the studied stages, the most critical in both cases was the production stage of the materials, causing more environmental damage. Fig. 3 summarizes the results studied for both materials (RC and G). In general, RC columns cause more damage in the three studied indicators. The results are analysed in detail: RC columns produce damage 3.5 times more than $\mathrm{G}$ columns to the ecosystem quality (excluding land occupation and exposed independently, because the general trend of the whole was ruled only by it). The RC columns require $32 \%$ more resources and affect $53 \%$ more the human health than the $\mathrm{G}$ columns.

With regard to the ecosystem quality, the data are separated because in some aspects their understanding is needed (Fig. 4). In land occupation indicator the $G$ columns cause damage 108 times higher than RC columns, attributed to excessive deforestation. However, if palliative, preventive and control environmental measures were considered, as moderate logging and, tree planting, this effect is mitigated because the wood is the only building material 100\% renewable (Barrera 2010) and also reusable.

In terms of acidification and eutrophication of the ecosystem, both materials have similar behaviour. However, G columns cause damage 15\% higher than RC columns, which is due to the compounds involved to obtain glues of melamine and resorcinol, (used in the gluing the wood layers). The process to get them involves elements such as nitrogen and sulphur, which are potential generators of acidification and eutrophication. In the same way, the RC involves these components in their production, due to reactions generated in the manufacturing of clinker and due to their chemical composition.

Continuing the interruption of ecosystem quality, the RC produces 5.4 times more ecotoxicity than the $\mathrm{G}$; the above is attributed to emissions generated by the production of cement clinker, to chemical reactions, and the burning of fossil fuels used (Carvalho-Filho 2001).

With regard to natural resources, it is necessary to indicate that both manufacturing industries (RC and $\mathrm{G}$ ) are consumers of fossil fuels, for example in the high temperatures for the calcination of clinker or
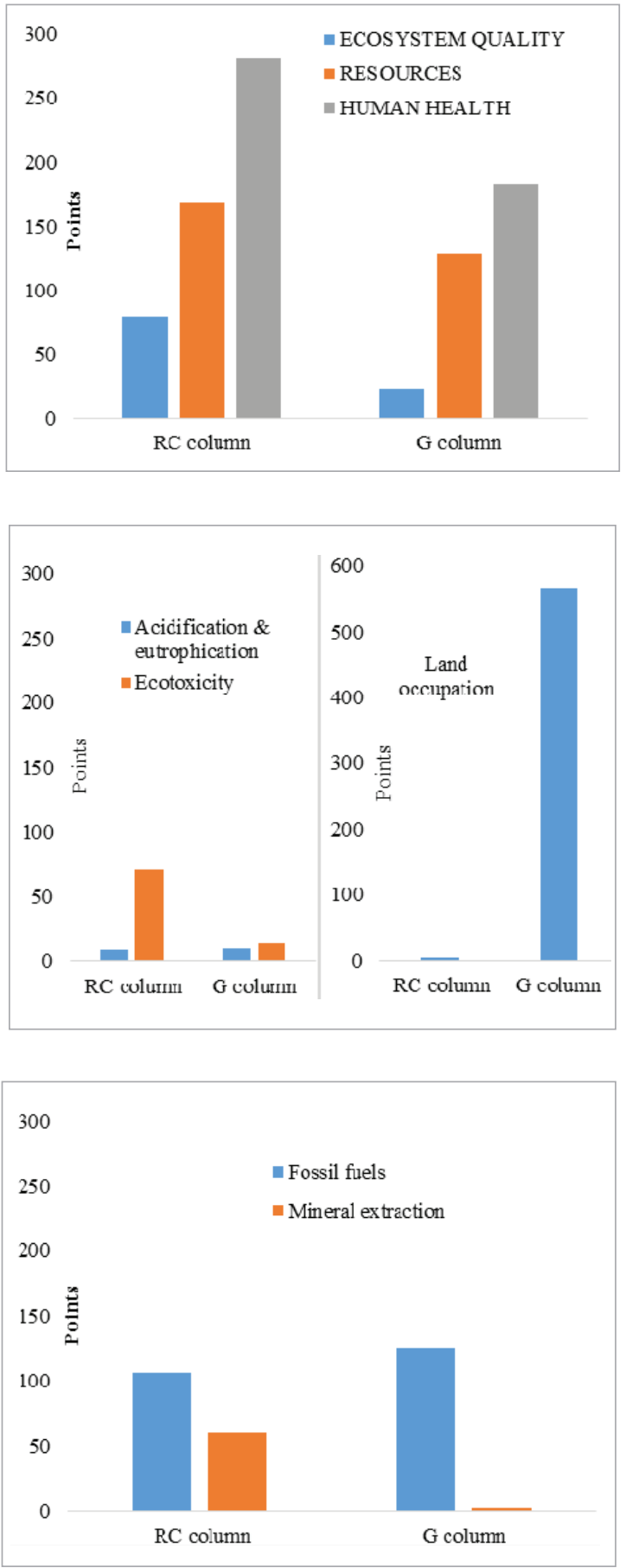

\section{Results}

Fig. 3

Summary of

eco-indicators

Fig. 4

Detail of

ecosystem quality

Fig. 5

Consumption of natural resources 


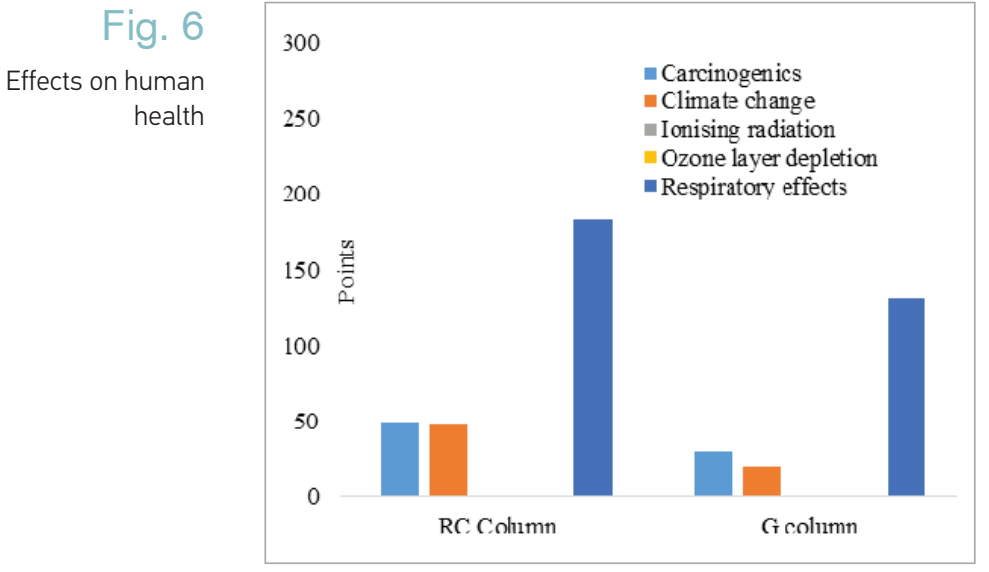

\section{Conclusions}

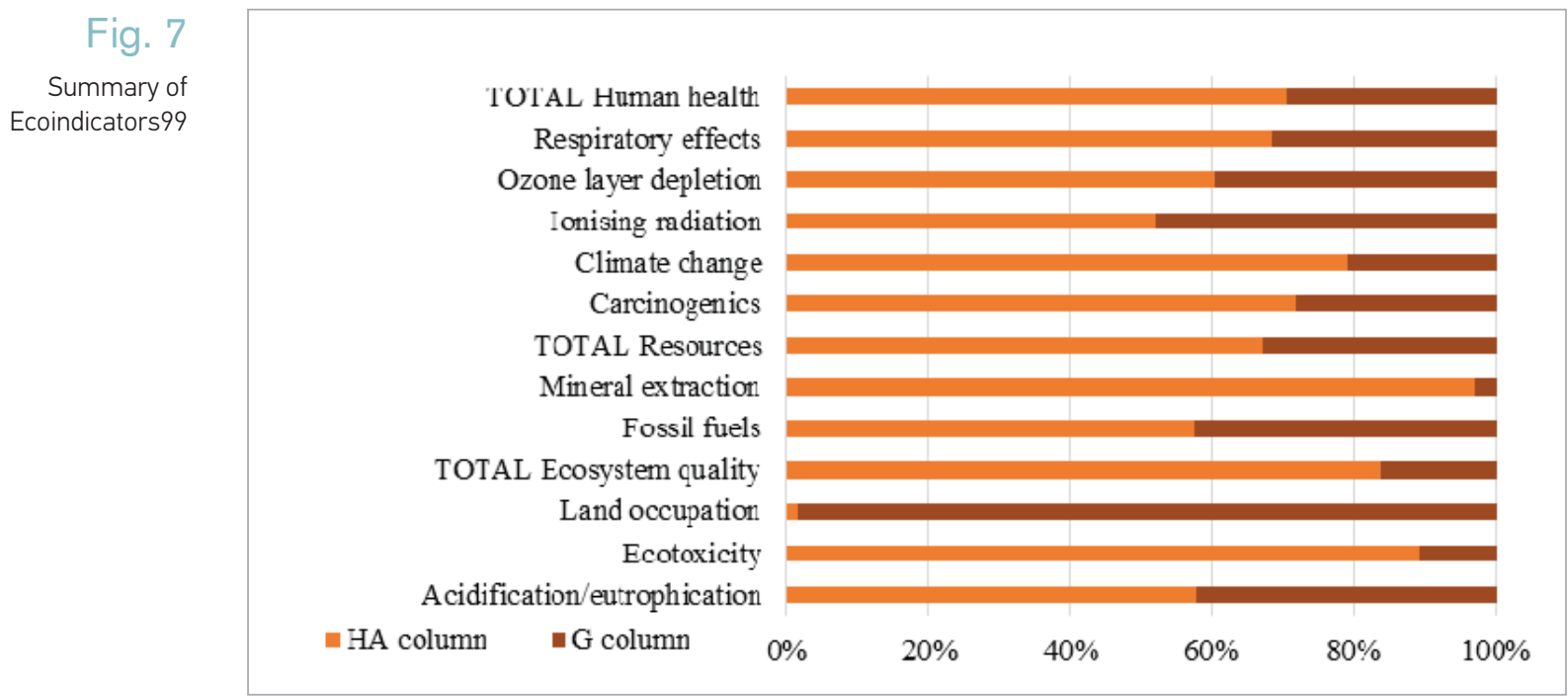

in the glues manufacturing, however this study shows that $G$ generates $15 \%$ more damage to consumption of fossil fuels that the RC. Concerning the extraction of minerals, $\mathrm{RC}$ is the largest consumer, being 22 times more burdensome than $G$ (Fig. 5). In addition to its relevant damage in the extraction of mineral resources above mentioned, it is necessary to underline that the $\mathrm{RC}$ is the second material most used on the planet (only surpassed by water). The current civilization is based on constructions that utilize it (Gaimster and Munn 2012), consuming in its production 12.6 billion tons of raw materials every year, what makes it the biggest consumer of natural resources in the world, and converts in the material with the highest environmental impact when is used with conventional methods (Deshpande et al. 2011).

Analysing the effects on health as a whole, RC columns produce $53 \%$ more damage than $\mathrm{G}$ columns (Fig. 6). The indicator of the respiratory effect is the most critical and is attributed specifically to the emissions of $\mathrm{CO}_{2}, \mathrm{NO}_{x}$ and $\mathrm{SO}_{2}$ (originated in chemical processes and the burning of fuels) resulting from the production of cement clinker and in the production of steel (Carvalho-Filho 2001).

Continuing with the effect on human health, both materials have low impact in radiation and ozone layer depletion, in comparison to the rest of the indicators. In terms of climate change, RC columns generate damage $37 \%$ higher than $\mathrm{G}$ columns (attributed to the emissions of $\mathrm{CO}_{2}, \mathrm{NO}_{x}$ and $\mathrm{SO}_{2}$ ), also generate $64 \%$ more agents carcinogenic (attributed to small quantities of heavy metals such as $\mathrm{Cd}, \mathrm{Cr}, \mathrm{Hg}, \mathrm{Pb}$, which are found by the use of fossil fuels or other types of alternative fuels (Carvalho-Filho 2001)).

Fig. 7 summarizes the effects of the eco-indicators. In this, it can observe that the columns of RC made with a conventional method produce more significant damage than the $G$ columns. Due to the nature of each material, the indicator of damage for land occupation is more obvious for 
$\mathrm{G}$ columns; it is also evident, in the extraction of minerals for the production of RC; both with a damage rate close to $100 \%$.

However, and although both are important consumers of these different raw materials it is noteworthy that $\mathrm{G}$ is a $100 \%$ renewable (and reusable) material. If an environmental management plan that allows its regeneration is implemented, and if tree felling rules are observed, $G$ is an alternative option to RC, considering an environmentally friendly construction.

Moreover, although the component materials of the RC are not renewable, they have a high potential for recycling (recycled aggregate to recycled concrete). Pretending to build with conventional $\mathrm{RC}$, is unsustainable, as in previous studies have been shown. By contrasts, the use of recycled components (the same concrete incorporated in new cycles as fine or coarse aggregates, wastes from other industries either as aggregates or as supplementary cementitious materials or as additives or additions; among others) in RC is a viable option to consider a sustainable construction.

It is important to mention that Ecoinvent is not a Spanish database. Although this study considered European average data and the results are consistent with the literature reviewed, it is evident the need to create local inventories to accurately assess environmental impacts.

Finally, the LCA was verified as feasible to use like Environmental Assessment Tool in the search for construction materials alternatives, in this case used like structural elements, comparing the environmental impacts generated by concrete columns and glulam columns. The LCA identified to the laminated wood as an alternative solution in the construction of vertical structural elements such as columns, finding that this could be an option for total replacement of conventional RC.

Althaus H.J., Kellenberger D., Doka G., Künniger T. Manufacturing and disposal of building materials and inventorying infrastructure in Ecoinvent. The International Journal of Life Cycle Assessment, 2005; 10(1): 35- 42. doi:10.1065/lca2004.11.181.4

Asif M., Muneer T., Kelley R. Life cycle assessment: a case study of a dwelling home in Scotland. Building and Environment, 2007; 42(3): 1391-1394. doi:10.1016/j.buildenv.2005.11.023

Aye L., Ngo T., Crawford R. H., Gammampila R., Mendis P. Life cycle greenhouse gas emissions and energy analysis of prefabricated reusable building modules. Energy and Buildings, 2012; 47 : 159-168. doi:10.1016/j.enbuild.2011.11.049

Barrera J. A. La madera laminada: una alternativa estructural y ambiental [The laminated wood: a structural and environmental alternative]. Revista M-M: 10-17. [www.revista-mm.com]. [Last access: 11-03-2015]

Bilec M., Ries R., Matthews H. S., Sharrard A. L. Example of a hybrid life cycle assessment of construction processes. Journal of Infrastructure Systems, 2006; 12(December): 207-215. doi:10.1061/(ASCE)1076-0342(2006)12:4(207)

Cabeza F. L., Rincón L., Vilariño V., Pérez G., Castell A. Life cycle assessment (LCA) and life cycle energy analysis (LCEA) of buildings and the building sector: a review. Renewable and Sustainable Energy Reviews, 2014; 29: 394-416.

De Carvalho Filho A. C. Tesis doctoral: análisis del ciclo de vida de productos derivados del cemento aportaciones al análisis de los inventarios del ciclo de vida del cemento [PhD Thesis: Analysis of the life cycle of products derived from cementcontributions to the analysis of life cycle inventories of cement]. Barcelona, España: Universidad Politécnica de Cataluña, 2001.

Deshpande N., Kulkarni S. S., Patil N. Effectiveness of using coarse recycled concrete aggregate in concrete. International Journal of Earth Sciences and Engineering, 2011: 4 (6): 913-919.

Dodoo A., Gustavsson L., Sathre R. Lifecycle primary energy analysis of low-energy timber building systems for multi-storey residential buildings. Energy and Buildings, 2014; 8: 84-97.

Ecoinvent Centre [www.ecoinvent.org]. [Last access: 11-03-2015]

Erlandsson M., Borg M. Generic LCA-methodology applicable for buildings, constructions and operation services-today practice and development needs. Building and Environmental, 2003; 38: 919938.

\section{References}


Fernández M., Martínez A., Alonso A., Lizondo L. A mathematical model for the sustainability of the use of cross-laminated timber in the construction industry: the case of Spain. Clean Technologies and Environmental Policy, 2014; 16: 1625-1636. DOI 10.1007/s10098-014-0738-3.

Gaimster R., Munn C. The role of concrete in sustainable development. New Zealand Concrete Society Annual Conference, 2007. [www. sustainableconcrete.org.nz]. [Last access: 11-032015]

Gobierno Vasco. Madera y cambio climático: análisis de ciclo de vida de la madera como material alternativo [Wood and climate change: life-cycle assessment of wood as an alternative material]. País Vasco: Colección LUR N. 14, 2009.

Horvath A., Hendrickson C. Steel versus steelreinforced concrete bridges: environmental assessment. Journal of Infrastructure Systems, 1998; 4(September): 111-117. doi:10.1061/ (ASCE)1076-0342(1998)4:3(111)

ISO 14040. Environmental management: life cycle assessment: principles and framework, 2006.

Kellenberger D., Althaus H.J. Relevance of simplifications in LCA of building components. Building and Environment, 2009; 44: 818-825. doi:10.1016/j.buildenv.2008.06.002

Khasreen M. M., Banfill P. F. G., Menzies, G. F. Lifecycle assessment and the environmental impact of buildings: A review. Sustainability, 2009; 1: 674701. doi:10.3390/su1030674

O’Reilly Díaz V. A., Bancrofft-Hernández R.A., RuizGutiérrez L. Las tecnologías del concreto en su ciclo de vida [The technologies of concrete in its life cycle]. Cemento y Concreto. Investigación y desarrollo, 2010; 1(2): 42-47. [www.scielo.org.mx]. [Last access: 11-03-2015].

Ortiz O., Castells F., Sonnemann G. Sustainability in the construction industry: a review of recent developments based on LCA. Construction and Building Materials, 2009; 23: 28-39.

Ortiz-Rodríguez O., Castells F., Sonnemann G. Life cycle assessment of two dwellings: one in Spain, a developed country, and one in Colombia, a country under development. Science of the Total Environment, 2010; 408: 2435-2443.

Perez-Garcia J., Lippke B., Comnick J., Manriquez C. An assessment of carbon pools, storage, and wood products market substitution using life-cycle analysis results. Wood and Fiber Science, 2005; 37: 140-148. Retrieved from http:// www.scopus.com/inward/record.url?eid=2-s2.032644488738\&partner|D=tZOtx3y1.

Peuportier B. L. P. Life cycle assessment applied to the comparative evaluation of single family houses in the French context. Energy and Buildings, 2001; 33: 443-450. doi:10.1016/S0378-7788(00)00101-8

Radhi H., Sharples S. Global warming implications of façade parameters: A life cycle assessment of residential buildings in Bahrain. Environmental Impact Assessment Review, 2013; 38: 99-108.

Ramesh T., Prakash R., Shuklab K.K. Life cycle energy analysis of buildings: an overview. Energy and Buildings, 2010; 42: 1592-1600.

Rivela B., Moreira M. T., Muñoz I., Rieradevall J., Feijoo G. Life cycle assessment of wood wastes: a case study of ephemeral architecture. Science of the Total Environment, 2006; 357: 1-11. doi:10.1016/j.scitotenv.2005.04.017

Simpple Efficient Solutions. Manual del usuario: LCA Manager versión 1.3 [User Manual: LCA Manager version 1.3]. Tarragona, España, 2010.

Utama N. A., Mclellan B.C., Gheewala S.H., Ishihara K.N. Embodied impacts of traditional clay versus modern concrete houses. Building and Environment, 2012; 57: 362-369.

Venkatarama R. B., Jagadish K. Embodied energy of common and alternative building materials and technologies. Energy and Buildings, 2003; 35(2): 129-137. doi:10.1016/S0378-7788(01)00141-4

Xiao J., Li W., Fan Y., Huang X. An overview of study on recycled aggregate concrete in China (19962011). Construction and Building Materials, 2012; 31: 364-383.

Xing S., Xu Z., Jun G. Inventory analysis of LCA on steel and concrete construction office buildings. Energy and Buildings, 2008; 40: 1188-1193.

Zabalza-Bribián I., Aranda-Usón A., Scarpellini S. Life cycle assessment in buildings: state-ofthe-art and simplified LCA methodology as a complement for building certification. Building and Environment, 2009; 44(12): 2510-2520. doi:10.1016/j.buildenv.2009.05.001

Zhang Z., Wua X., Yanga X., Zhub Y. BEPAS - a life cycle building environmental performance assessment model. Building and Environment, 2006; 41: 669-675. 


\section{DIANA CAROLINA GÁMEZ-GARCÍA}

\section{$\mathrm{PhD}$ student}

Polytechnic University of Cataluña, School of architecture of Barcelona, Department of Building Architectural

Main research area

LCA in construction, recycled concrete

\section{Address:}

Av. Diagonal, 649-651, 08028, Barcelona, Spain

Tel. +34934016242

E-mail: diana.carolina.gamez@ estudiant.upc.edu

\section{JORGE LUIS ALMARAL-SÁNCHEZ}

Full time Professor

Autonomous University of Sinaloa, School of engineering of Mochis

Main Research areas

Concrete Technology, sustainable concretes characterization techniques applied to pastes, mortars and concretes, and sustainability in construction

\section{Address}

Fuente de Poseidón y Ángel Flores s/n pte., 81223, Los Mochis, Sinaloa, Mexico Tel. +52 (668) 812-7641

E-mail: jalmaral@uas.edu.mx
JOSÉ MANUEL GÓMEZ-SOBERÓN

Full time Professor

Polytechnic University of Cataluña, School of Building Construction of Barcelona, Department of Building Architectural II

\section{Main research area}

Concrete recycled, porous structure of concrete, sustainable construction, minimization, reuse and recycling in construction, ICT in teaching, virtual campus teachers

\section{Address}

Doctor Marañón, 44-50, 08028,

Barcelona, Spain

Tel. +34934016242

E-mail: josemanuel.gomez@upc.edu

\section{MARÍA CONSOLACIÓN GÓMEZ-SOBERÓN}

Full time Professor

Metropolitan Autonomous

University. School of Civil

Engineering, Department of

Materials

\section{Main research area}

Vulnerability of structures and bridges

\section{Address}

Av. San Pablo No. 180. Col. Reynosa Tamaulipas, 02200. Delegación Azcapotzalco. Distrito Federal. Mexico

Tel. +34 12454520134

E-mail:cgomez@correo.azc.uam.mx

\section{RAMÓN \\ CORRAL-HIGUERA}

Full time Professor

Autonomous University of Sinaloa, School of engineering of Mochis

\section{Main Research area}

Concrete Technology, sustainable concretes characterization techniques applied to pastes, mortars and concretes, and sustainability in construction

\section{Address}

Fuente de Poseidón y Ángel Flores s/n pte., 81223, Los Mochis,

Sinaloa, Mexico

Tel. +52 (668) 812-7641

E-mail: rmn1779@gmail.com

\section{LUIS ALBERTO GÓMEZ-SOBERÓN}

Professional structural designer

Alonso y Asociados

Main research area

Structural design of buildings, seismic performance of buildings

Address

Paseo de la Palma no. 150-101. Colonia Lomas de Vista Hermosa. Delegación Coajimalpa. México, D.F. 05100. Mexico Tel. +34 12454520134 E-mail: laags@hotmail.com

\section{About the authors}

